\title{
Multiclass SVM Algorithm For Sarcasm Text In Twitter
}

\author{
Debby Alita*1, Yusra Fernando ${ }^{2}$ \\ ${ }^{1,2}$ Program Stufi Informatika, Fakultas Teknik dan Ilmu Komputer, Universitas Teknokrat \\ Indonesia, Bandar Lampung \\ e-mail: *1debbyalita@teknokrat.ac.id., 2yusrafernando@teknokrat.ac.id
}

\begin{abstract}
Abstrak
Penelitian dibidang text mining sekarang ini semakin marak dilakukan karena berbagai industry dan tokoh public yang ingin mendapatkan informasi terkait pendapat publik tentang produk atau penilaian individual yang didapatkan dari media social baik pendapat yang bersifat pendapat biasa maupun sarkasme. Pada proses melakukan text mining banyak sekali metode klasifikasi yang dapat digunakan, salah satunya yaitu metode Support Vector Machine yang dapat dioptimasi sehingga bisa mengklasifikasikan data menjadi tiga kelas klasifikasi yaitu SVM One Againts One (OAO) dan One Againts All (OAA). Data yang digunakan pada penelitian adalah sebanyak 2072 data yang berasal dari media social twitter. Hasil yang didapatkan dari penelitian ini adalah nilai akurasi yang memiliki nilai yang sama besarnya baik yang dilakukan secara acak maupun tidak acak dengan nilai sebesar 60,82\% dilakukan secara acak dan 60,93\% secara tidak acak. Pada nilai lainnya seperti presisi, recall dan F1score metode SVM One Againts All memiliki nilai yang lebih unggul dibandingkan dengan nilai SVM One Againts One.
\end{abstract}

Kata kunci-3-5 Text Mining, Support Vector Machine, One Againts One, One Againts All, sarkasme

\begin{abstract}
Research in the field of text mining is now increasingly being carried out because of various industries and public figures who want to get information related to public opinion about products or individual assessments obtained from social media, both opinions that are ordinary opinions and sarcasm. In the process of doing text mining, there are many classification methods that can be used, one of which is the Support Vector Machine method which can be optimized so that it can classify data into three classification classes, namely SVM One Against One and One Against Rest. The data used in the study were 2072 data from social media twitter. The results obtained from this study are the accuracy value which has the same value, whether it is done randomly or not randomly, with a value of $60.82 \%$ randomized and $60.93 \%$ non-random. On other values such as precision, recall and F1 score, the SVM One Against Rest method has a superior value compared to the SVM One Against One value.
\end{abstract}

Keywords-3-5 Text Mining, Support Vector Machine, One Againts One, One Againts All; sarcasm

\section{PENDAHULUAN}

Saat ini penelitian dibidang text mining semakin banyak dikarenakan kebutuhan informasi mengenai individual atau publik figur terhadap penilaian orang lain kepada dirinya, tidak hanya itu perusahaan atau pemilik usaha yang sangat ingin mengetahui informasi 
mengenai produknya di mata pengguna begitu sangat penting untuk diketahui, text mining itu sendiri merupakan proses pengolahan kata yang didalamnya terdapat proses preprocessing dokumen [1]. Penilaian seseorang terhadap publik figure kini sangat marak diperbincangkan di media sosial twitter mulai dari opini yang bersifat positif hingga negatif, selain kedua opini tersebut terdapat juga opini yang bersifat sarkasme. Sarkasme sendiri merupakan opini yang mengandung kata sindiran terhadap seseorang ataupun suatu produk dengan menggunakan katakata yang positif tetapi bermakna negatif [2].

Twitter merupakan salah satu media social yang hingga saat ini masih sangat digunakan oleh masyarakt Indonesia untuk berbagi informasi atau bahkan untuk memberikan sebuah opini terhadap suatu trending topic [3]. Kemudahan dalam menganalisis data dan memperoleh data opini dari twitter membuat peneliti sangat terbantu dalam melakukan penelitian mengenai analisis sentimen yang kemudian data tersebut akan dijadikan sebgai sumber informasi bagi yang membutuhkan [4].

Proses analisis sentiment itu sendiri merupakan proses pengeolahan data teks yang dilakukan oleh system untuk mengetahui penilaian seseorang terhadap suatu produk, jasa atau tokoh publik [5]. Pada penelitian ini data yang akan digunakan adalah data tentang penilaian terhadap jejaring telekomunikasi selular, pemadaman listrik pada pln, pelayanan BPJS dan terakhir tentagn tokoh publik bapak Presiden Joko Widodo. Pada proses pengklasifikasian data akan digunakan metode Support Vector Machine (SVM) yang telah dioptimasi sehingga dapat melakukan tahapan klasifikasi dengan menggunakan lebih dari dua kelas.

Metode SVM merupakan metode klasifikasi yang pada proses kerjanya menggunakan ruang hipotesis yang terdiri dari fungsi linear bersifat dua arah dalam sebuah ruang fitur yang berdimensi tinggi sehingga SVM pada umunya selalu digunakan untuk pengklasifikasian data yang hanya memiliki dua kelas saja [6]. SVM sering digunakan dalam berbagai masalah termasuk pengenalan pola, bioinformatika dan kategori teks dengan menguraikan hyperplane sebagai set input kedalam ruang fitur yang terdiri dari dua kelas tetapi kemudian dioptimasi kembali sehingga dapat digunakan kedalam bentuk lebih dari dua kelas [7]. Hasil optimasi SVM didapatkan 3 metode turunan SVM yang dapat digunakna untuk klasifikasi multi kelas yaitu SVM One Againts All, SVM One Againts One dan DAGSVM. Hanya saja penelitian ini hanya menerapkan dua metode saja yaitu SVM One Againts All dan SVM One Agiants One. Tujuan dari penelitian ini yaitu untuk mengetahui performa dari kedua metode tersebut jika digunakan dalam proses pendeteksian sarkasme pada analisis sentikmen berbahasa Indonesia.

\section{METODE PENELITIAN}

Tahapan pnelitian dimulai dari pengambilan data kemudian dilakukan proses analisis sentiment, selanjutnya dilakukan proses pendeteksian sarkasme dan terakhir pengujian dengan menggunakan metode multiclass SVM. Brikut merupakan gambar tahapan penelitian yang dapat dilihat pada Gambar 1.

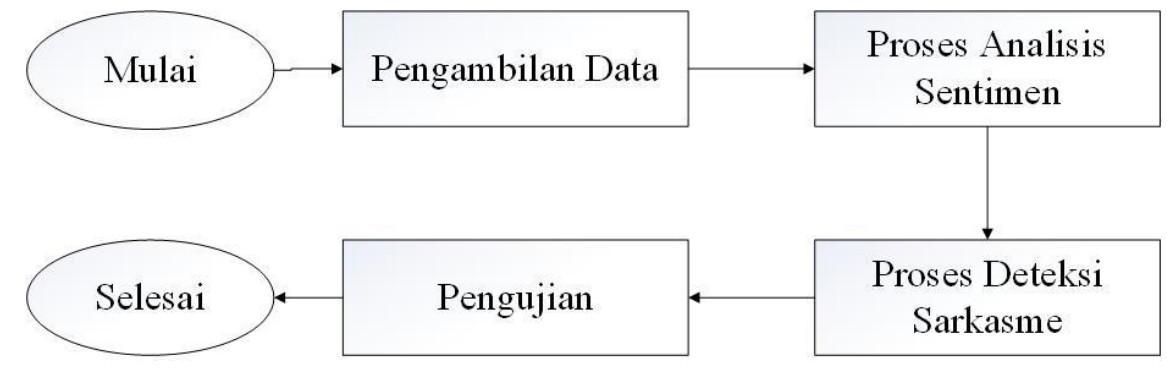

Gambar 1. Tahapan Penelitian 


\subsection{Pengambilan Data}

Data didapatkan dari media social twitter dengan menggunakan API twitter yang telah disediakan oleh twitter untuk memudahkan para peneliti dalam pengambilan data [8].

\subsection{Proses Analisis Sentimen}

Tahapan pertama pada proses analisis sentiment adalah melakukan labeling data secara manual, data yang telah di labelkan kemudian dilakukan tahapan preprocessing yaitu proses pengelohan data tekstual dan mengklasifikasikannya kedalam kalimat positif, negatif atau netral dengan membersihkan kata-kata yang tidak memiliki arti, merubah kata yang tidak baku menjadi baku, menyetarakan kata, dan lain sebagainya [9], kemudian setelah dilakukan tahapan preprocessing dilakukan proses klasifikasi menggunakan metode multiclass SVM, kemudian ekstraksi fitur dan tahapan terakhir adalah pengujian pada proses analisis sentimen dan proses pendeteksian sarkasme.

\section{$2.3 \quad$ Preprocessing}

\subsubsection{Casefolding}

Merupakan proses meyamaratakan semua huruf sehingga tidak ada perbedaan antar huruf satu dengan huruf lainnya seperti merubahnya menjadi huruf yang kecil.

\section{Tabel 1. Contoh Casefolding}

\section{Tweet Hasil Preprocessing}

@Telkomsel @agus_pinoa tutup halo aja gus, @ telkomsel @agus_pinoa tutup halo aja ganti simpati. Lebih hemat. Kualitas sinyal gus, ganti simpati. lebih hemat. kualitas sama. Percayalah :-D sinyal sama. percayalah :-d

\subsubsection{Tokenisasi}

Merupakan proses untuk memisahkan kata/word dengan spasi, dll.

Tabel 2. Contoh Tokenisasi

\begin{tabular}{ll}
\hline \multicolumn{1}{c}{ Tweet } & \multicolumn{1}{c}{ Hasil Preprocessing } \\
\hline @ Telkomsel @agus_pinoa tutup halo aja & @telkomsel @agus_pinoa tutup halo aja \\
gus, ganti simpati. Lebih hemat. Kualitas & gus, ganti simpati. lebih hemat. kualitas \\
sinyal sama. Percayalah :-D & sinyal sama. percayalah :-d \\
\hline
\end{tabular}

\subsubsection{Stopword} dihilangkan.

Merupakan proses memeriksa apakah terdapat kata yang tidak sesuai dan kemudian

Tabel 3. Contoh Stopword

Tweet Hasil Preprocessing

@ telkomsel @agus_pinoa tutup halo aja gus, tutup halo aja ganti simpati lebih ganti simpati. lebih hemat. kualitas sinyal sama. hemat kualitas sinyal sama percayalah percayalah :-d $:-\mathrm{d}$

\subsubsection{Convert Emoticon}

Merupakan proses menggantikan emoticon pada tweet kedalam string yang bersesuaian. Berikut merupakan kamus emoticon 
Tabel 4. Kamus Emoticon

\begin{tabular}{|c|c|c|}
\hline Emoticon & Konversi & Sentimen \\
\hline :-) >:] :) :o) :] :3:c) :> =] 8) =) :\} :^) & esenang & Positif \\
\hline$: D>: D$ :-D 8-D x-D xD XD =-D =D =-3 =3 & etertawa & Positif \\
\hline$>:\left[\& \&:\right.$ :-c :c :-<:<:-[ :[ : $\left\{>.><.>.<:^{\prime}(\right.$ & esedih & Negatif \\
\hline $\mathrm{D}:<\mathrm{D}: \mathrm{D} 8 \mathrm{D} ; \mathrm{D}=\mathrm{DX}$ v.v D-‘: & ehoror & Negatif \\
\hline$>: P$ :-P :P X-P x-p xp XP :-p :p =p :-b :b & etongue & Positif \\
\hline$>: 0$ >:O :-O :O o_O o.O 8-0 & eshock & Positif \\
\hline$>: \mid>: /:-/:-.: /: \backslash=/=\backslash: S$ & ekesal & Negatif \\
\hline$:|:-|$ & edatar & Netral \\
\hline
\end{tabular}

Tabel 5. Contoh Convert Emoticon

Tweet

tutup halo aja ganti simpati lebih hemat kualitas sinyal sama percayalah :-d

\section{Hasil Preprocessing}

tutup halo aja ganti simpati lebih hemat kualitas sinyal sama percayalah etertawa

\subsection{Slangword}

Merupakan proses mengubah kata yang tidak ada dalam kamus menjadi kata standar dengan mengamati pola kemunculan kata nonstandar.

Tabel 6. Contoh Slangword

\begin{tabular}{ll}
\hline \multicolumn{1}{c}{ Tweet } & \multicolumn{1}{c}{ Hasil Preprocessing } \\
\hline $\begin{array}{l}\text { tutup halo aja ganti simpati lebih hemat kualitas } \\
\text { sinyal sama percayalah etertawa }\end{array}$ & $\begin{array}{l}\text { tutup halo saja ganti simpati lebih hemat } \\
\text { kualitas sinyal sama percaya etertawa }\end{array}$ \\
\hline
\end{tabular}

3 Ekstraksi Fitur

Proses ekstraksi ciri digunakan untuk mencari fitur-fitur yang ada pada suatu teks, ekstraksi ciri yang digunakan dalam penelitian ini adalah

1) Unigram

Dalam proses unigram, data tweet akan dipotong berdasarkan spasi dan digunakan sebagai fitur.

Tabel 7. Contoh Hasil Unigram

\section{Tweet Unigram}

tutup halo aja ganti simpati lebih hemat kualitas "tutup", "halo", "saja", "ganti", "simpati", sinyal sama percayalah etertawa "lebih", "hemat", "kualitas", "sinyal", "sama", "percaya", "etertawa"

2) POS Tagging

Pada proses POS Tagging, kelas kata akan dibagi menjadi beberapa kategori, dan selama proses penentuan fitur akan dipilih kata dengan kategori tag kata sifat dan kata kerja. 
Tabel 8. Contoh Hasil POS Tagging

\begin{tabular}{llr}
\hline Tweet & \multicolumn{2}{c}{ Hasil POS Tagging } \\
\hline $\begin{array}{l}\text { tutup halo aja ganti simpati lebih hemat } \\
\text { kualitas sinyal sama percayalah etertawa }\end{array}$ & [('tutup','VB'), & \multicolumn{1}{c}{ ('halo','NN'), } \\
& ('saja','RB'), ('simpati','NN'), & ('ganti', ('lebih','RB'), \\
& ('hemat','JJ'), & ('kualitas','RB'), \\
& ('sinyal','RB'), ('sama','RB'), \\
& ('percaya','JJ'), ('etertawa','VB')] \\
\hline
\end{tabular}

3) TF dan TFIDF

TF dan TF-IDF merupakan proses pembobotan fitur kata pada tweet.

Kemudian menggunakan metode optimasi SVM untuk dilakukan klasifikasi pada sentimen analisis. Kemudia hasil klasifikasi dengan label positif akan di proses kembali untuk dilakukan pendeteksian sarkasme, jika hasil data tersebut merupakan data sarkasme maka label kalimat tersebut akan berubah menjadi label negatif.

\subsection{Proses Deteksi Sarkasme}

Pendeteksian sarkasme dilakukan pada tweet dengan label positif pada hasil klasifikasi analisis senitmen. Kemudian kata-kata pada kalimat tersebut diekstraksi pada pendekatan sarkasme terdiri dari fitur sentiment-relate, punctuation-relate, lexical dan syntactic, dan patternrelate.

\section{Sentiment-relate feature}

Pada tahapan ini terdapat 10 fitur yang diekstraksi yaitu menentukan jumlah kata berupa kata opini yang memiliki kecenderungan bersifat positif atau negative.

Fitur kedua, ketiga, dan keempat yang diekstrak adalah jumlah emoticon positif, negatif, dan sarkasme. Fitur kelima dan keenam yaitu dengan menentukan jumlah hashtag pada tweet. Jumlah hashtag positif dan negatif dihitung dan dijadikan fitur. Fitur ketujuh sampai dengan fitur kesepuluh menggambarkan kontras antar komponen, di mana terdapat negatif dan positif komponen dalam satu tweet dengan urutan yang pertama adalah komponen kata dengan kata, kedua komponen hashtag dengan hashtag, ketiga komponen kata dengan hastag, dan terakhir komponen kata dengan emoticon.

2. Punctuation-Relate Feature

Pada set fitur punctuation-ralate, terdapat 6 fitur yang akan diektraksi. Fitur pertama dengan menghitung jumlah tanda seru, fitur kedua menghitung jumlah tanda tanya, fitur ketiga menghitung jumlah titik, fitur keempat menghitung jumlah kata yang semua hurufnya kapital, fitur kelima menghitung jumlah kutipan kata, dan fitur terakhir yaitu menghitung jumlah pengulangan huruf yang sama lebih dari 2 kali pada suatu kata.

3. Lexical and Syntatic Feature

Pada set fitur ini terdapat 4 fitur yang akan diekstraksi yaitu Jumlah tawa, jumlah kata seru, keberadaan dan jumlah kata yang jarang digunakan, keberadaan pola umum kalimat sarkasme.

4. Pattern Relate Feature

Pada tahapan ini membuat pola umum kalimat sarkasme dan selanjutnya membuat daftar pola sarkasme berdasarkan panjang pola sarkasme.

\subsection{Klasifikasi Menggunakan Multiclass SVM}

Proses SVM bertujuan untuk mencari vektor $\alpha$ dan konstanta $b$ yang akan digunakan untuk mencari fungsi pemisah (hyperplane) dengan margin terbesar. Vektor $\alpha>0$ disebut vektor pembawa dan mewakili data pelatihan yang diperlukan untuk merepresentasikan fungsi 
keputusan terbaik. Konstanta b menentukan posisi fungsi pemisah relatif terhadap permulaan. Selama proses pembelajaran, Anda perlu memasukkan set data input/output, atau dalam hal ini, dokumen dengan kelas positif, negatif dan netral akan digunakan. Untuk studi SVM nonlinier ini, perlu menggunakan fungsi kernel atau teknik kernel. Fungsi kernel yang digunakan dalam penelitian ini adalah fungsi kernel RBF. Berikut adalah blok diagram proses pelatihan menggunakan SVM yang dapat dilihat pada gambar 2 .

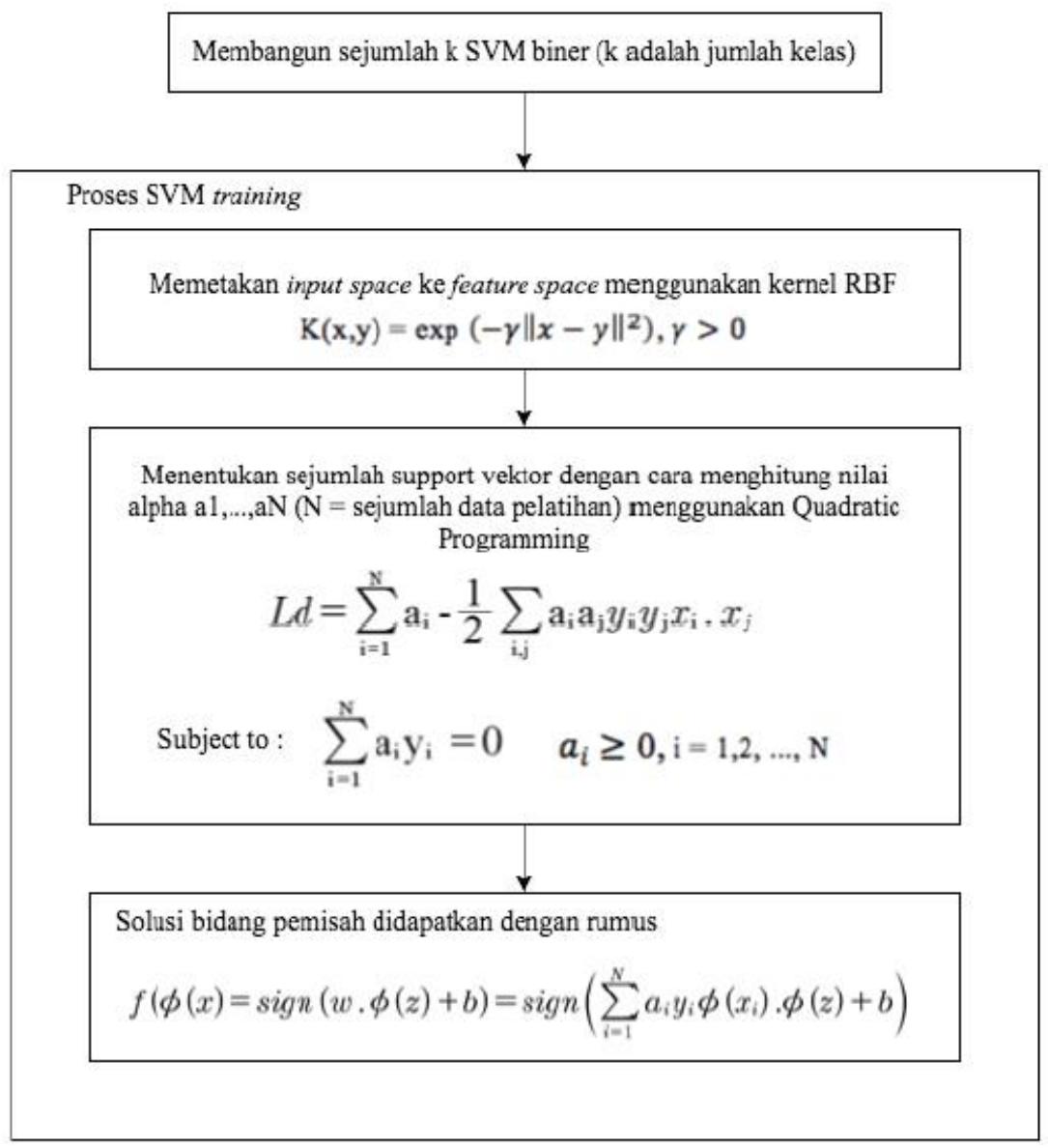

Gambar 2. Blok Diagram Proses Multiclass SVM

1. Analisis Training OAA

Dengan menggunakan metode ini, dalam kasus masalah klasifikasi kelas-k, kita temukan fungsi pemisah k, di mana k adalah jumlah kelas. Misalkan ada fungsi pemisah nama $\rho$. Dalam metode ini, $\rho^{\mathrm{i}}$ dilatih dengan semua data kelas I berlabel +1 dan semua data kelas lain berlabel -1 . Langkah selanjutnya adalah menghitung nilai $\mathrm{x}$. Nilai $\mathrm{x}$ dalam tabel akan digunakan untuk perhitungan kernel atau perhitungan dot product. Langkah selanjutnya adalah menggunakan fungsi kernel RBF untuk kernelisasi, yang didefinisikan sebagai $\mathrm{K}(\mathrm{x}, \mathrm{y})=\exp \left(-\gamma\|\mathrm{x}-\mathrm{y}\|^{2}\right), \gamma>0$.

Selanjutnya, kumpulan data dari fitur dimensi lama harus di-kernel untuk mendapatkan kumpulan data dengan fitur dimensi tinggi yang baru. Dengan kernel $\mathrm{K}(\mathrm{x}, \mathrm{y})=\exp \left(-\gamma\|\mathrm{x}-\mathrm{y}\|^{2}\right), \gamma>0$, Kumpulan data dengan dimensi $\mathrm{Nx} 1$ akan mendapatkan dimensi baru $\mathrm{NxN}$, dimana $\mathrm{N}$ adalah jumlah datanya.

2. Analisis Training $\mathrm{OAO}$

Dengan menggunakan metode ini, perlu dicari fungsi separator $\mathrm{k}(\mathrm{k}-1)$ / 2, di mana setiap fungsi dilatih menggunakan data dari dua kategori. Selain itu, kumpulan data dari fitur dimensi lama dikernel untuk mendapatkan kumpulan data dengan fitur dimensi tinggi baru. Dengan kernel $\mathrm{K}(\mathrm{x}, \mathrm{xi})=$ $\exp \left(-\gamma\|\mathrm{x}-\mathrm{y}\|^{2}\right), \gamma>0$, kumpulan data dengan dimensi Nx1 akan mendapatkan dimensi baru NxN, 
dimana $\mathrm{N}$ adalah jumlah datanya.

3. Analisis proses SVM Testing

Setelah mendapatkan model prediksi, selanjutnya dapat menentukan data masuk ke dalam kelas positif atau negatif dengan nilai w dan hyperplane dari data training. Jika nilai hasil uji lebih besar dari nilai hyperplane maka abstrak tersebut masuk dalam kelas positif, jika lebih kecil dari nilai hyperplane maka abstrak tersebut masuk dalam kelas negatif. Sebagai contoh, data satu uji dilakukan sebuah data testing yang kemudian akan diolah melalui Preprocessing dan Pembobotan TF IDF.

Metode "One-against-All" salah satunya. Pada bilangan SVM biner k, di mana k adalah nomor kelasnya. Untuk setiap model klasifikasi ke-i, dilatih untuk menggunakan seluruh data untuk menemukan solusi dari masalah tersebut. Misalnya, untuk masalah klasifikasi dengan total 3 kelas, digunakan 3 SVM biner dan digunakan untuk mengklasifikasikan data baru. Kemudian tentukan kategori data / objek x baru sesuai dengan nilai maksimum fungsi pemisah.

Metode "One-against-one" terdiri dari k (k-1) / 2 jumlah SVM biner, di mana k adalah jumlah kelas. Untuk setiap model klasifikasi ke-i, latih untuk menggunakan seluruh data guna menemukan solusi dari masalah tersebut. Misalnya, untuk masalah klasifikasi dengan 3 kelas total, digunakan 6 SVM biner, dan digunakan untuk data baru.

\section{HASIL DAN PEMBAHASAN}

Tahap pengujian dan evaluasi digunakan untuk mengukur performa pada sebuah sistem yang dibangun. Metode yang digunakan adalah confusion matrix dan K-fold Cross Validation. Validasi $K$-fold cross adalah metode membagi kumpulan data acak menjadi $k$ subset [10].

Pengumpulan data dilakukan dengan cara scraping. Proses scraping dilakukan dengan memanfaatkan library Python BeautifulSoup dan Fake User Agents dengan ua.chrome yang merupakan identitas dari browser yang sedang digunakan. Implementasi scraping data pada penelitian ini diperlihatkan pada gambar 3

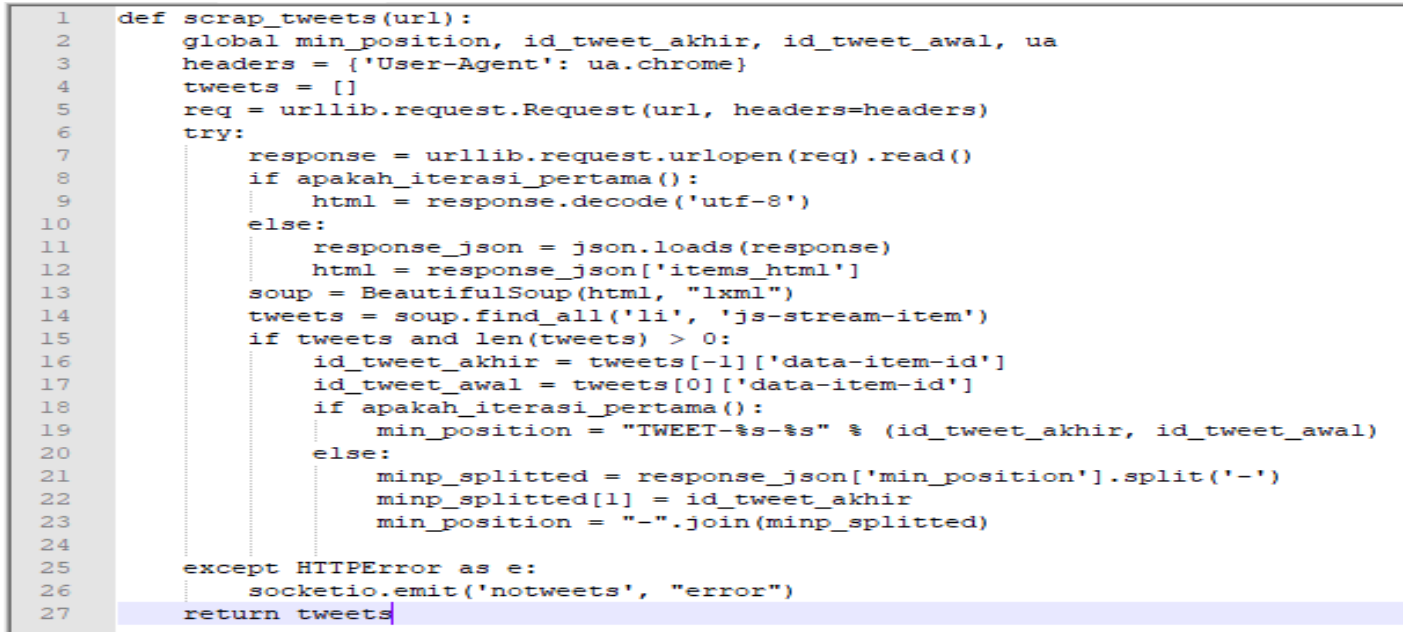

Gambar 3. Cuplikan Implementasi Pengumpulan Data

Jumlah total data yang digunakan dari Twitter adalah 2.281 data sentimen tweet yang didapat dari potongan data. Pada tahap preprocessing volume data berkurang karena data tidak memenuhi aturan tahapan proses preprocessing. sehingga data menjadi sebanyak 2.072. Pada data untuk pendeteksian sarkasme didapat dari data yang memiliki label positif pada proses analisis sentimen dan memperoleh jumlah data sebanyak 1.832 dengan rincian 520 merupakan data berlabel sarkasme dan 1.312 merupakan data tidak sarkasme. 
Contoh penggunaan aplikasi pencarian data di twitter dengan menginputkan nama grup berdasarkan merek, nama perusahaan, dan pemerintahan, kemudian menginputkan limit data perhari, kata kunci, tahun, bulan, hashtag, mention, kiriman dari:@user, kiriman untuk:@user. Data akan diambil disetiap tanggalnya selama satu bulan sesuai dengan data bulan yang diinputkan. Tweet statistic merupakan grafik jumlah data tweet yang sudah terkumpul berdasarkan nama grup dan jumlah tweet yang didapatkan.

\section{Analisis Sentimen}

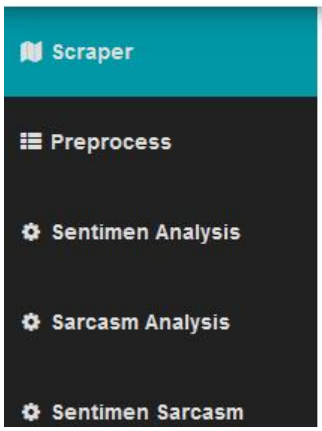

\section{Twitter Scrapper}

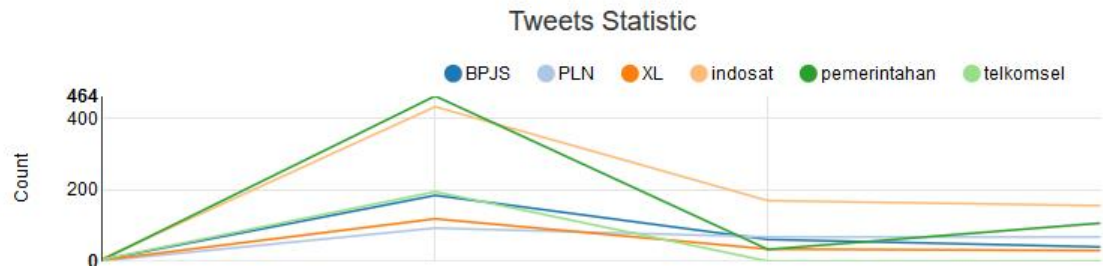

Gambar 4. Contoh Penggunaan Aplikasi

Data yang sudah didapatkan kemudian dilakukan tahapan preprocessing data untuk mempermudah dalam proses klasifikasi data. Pada gambar 5 dapat dilihat data terdiri dari dua baris, baris pertama merupakan data hasil preprocessing dan baris kedua merupakan data asli hasil proses scraping data. Berikut merupakan gambar tampilan proses preprocessing yang dapat dilihat pada gambar 5 .

(o) Analisis Sentimen

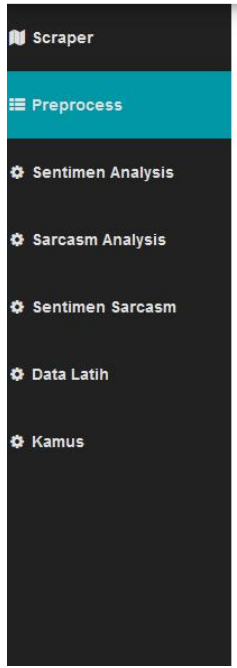

Pre-processing

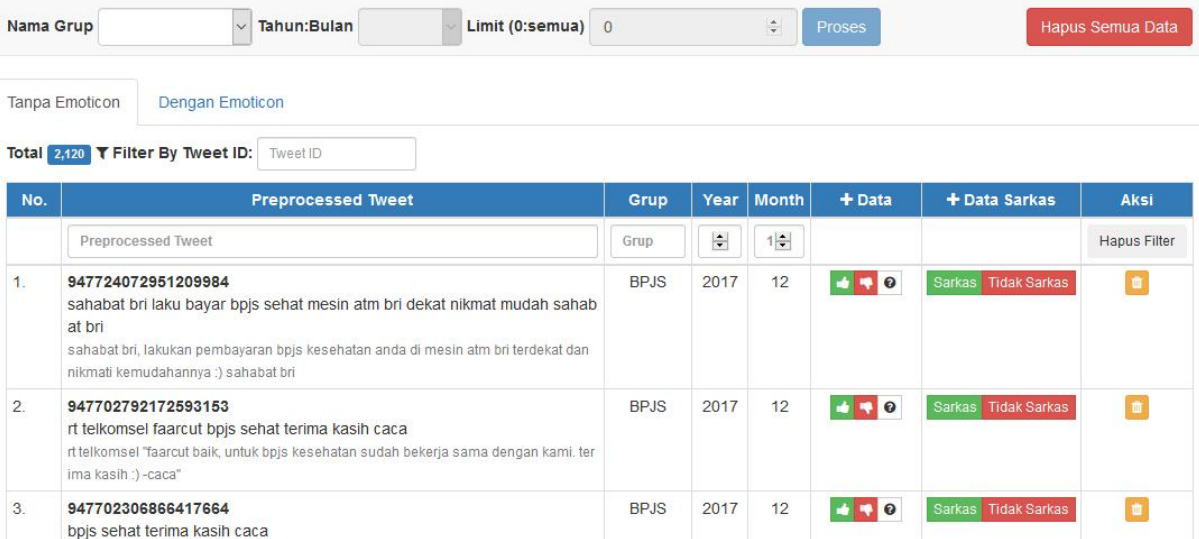

Gambar 5. Contoh Halaman Preprocessing

Data yang telah melalui tahapan preprocessing kemudian akan dilakukan proses klasifikasi dan pengujian analisis sentimen dengan menggunakan pengujian 10 Fold cross validation. Pengaturan pengujian merupakan perintah untuk mengatur proses pengujian dan klasifikasi dengan menentukan jumlah $N$-Fold. Berikut merpakan gambar tampilan proses klasifikasi dapat diihat pada gambar 6. 


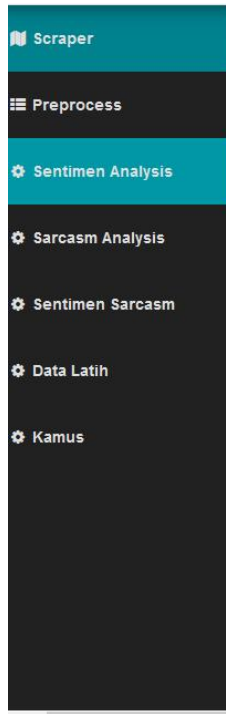

KFold Testing

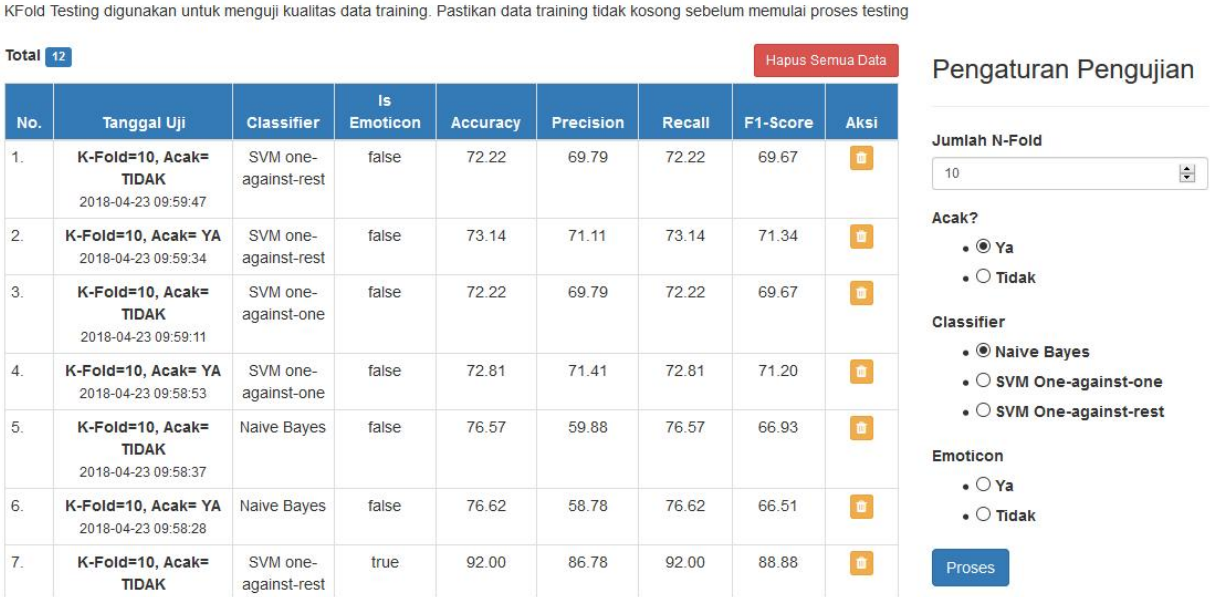

Gambar 6. Contoh Tampilan Proses Klasifikasi

Selanjutnya merupakan proses pengujian analisis sentiment dengan pendeteksian sarkasme yang dapat dilihat pada gambar 7 yang dilakukan dengan pengujian 10-Fold cross validation. Pengujian ini dilakukan untuk mengukur kualitas dari proses analisis sentimen setelah dilakukan pendeteksian sarkasme.

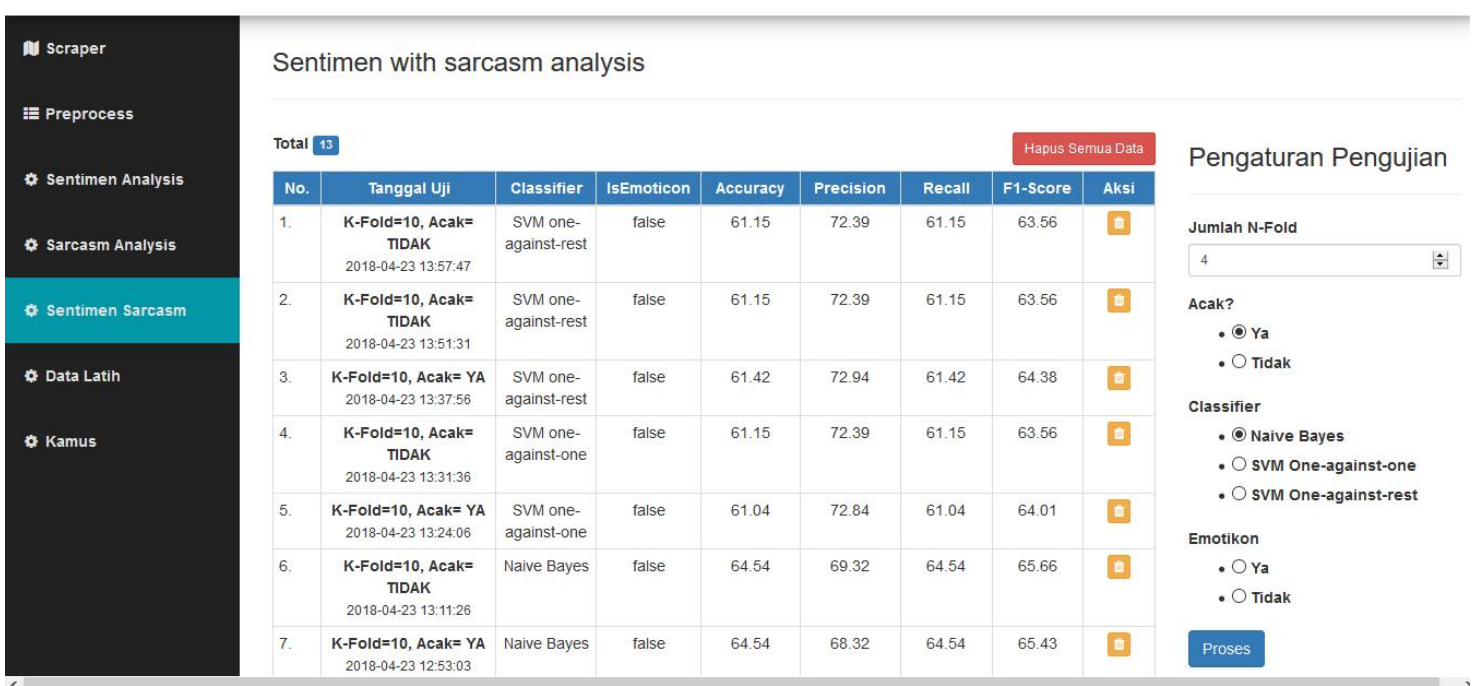

Gambar 7. Contoh Tampilan Klasifikasi Sarkasme

Pada Tabel 9 Anda dapat melihat hasil uji analisis sentimen menggunakan metode "oneto-one" dan "one-to-all" SVM serta sistem pengujian 10Fold Cross Validation. Pengujian dapat dilakukan secara acak atau tidak. 
Tabel 9. Nilai Ukuran Kualitas Akurasi

\begin{tabular}{rlcccc}
\hline Metode & $\begin{array}{c}\text { 10 Fold Cross } \\
\text { Validation }\end{array}$ & $\begin{array}{c}\text { Nilai } \\
\text { Akurasi }\end{array}$ & $\begin{array}{c}\text { Nilai } \\
\text { Presisi }\end{array}$ & $\begin{array}{c}\text { Nilai } \\
\text { Recall }\end{array}$ & $\begin{array}{c}\text { Nilai } \\
\text { F1Score }\end{array}$ \\
\hline SVM OAA & Acak & $93 \%$ & $87,02 \%$ & $93 \%$ & $89,98 \%$ \\
& Tidak Acak & $93 \%$ & $87,68 \%$ & $93 \%$ & $89,89 \%$ \\
SVM OAO & Acak & $92,04 \%$ & $87,94 \%$ & $92.85 \%$ & $90 \%$ \\
& Tidak Acak & $93 \%$ & $87,89 \%$ & $93 \%$ & $89,89 \%$ \\
\hline
\end{tabular}

Melalui penggunaan SVM OAO dan OAA untuk mendeteksi hasil pengujian analisis sentimen sarkasme, dan penggunaan sistem pengujian 10Fold Cross Validation dapat dilakukan secara acak atau tidak. Anda bisa lihat metrik kualitas pengujian analisis sentimen pada Tabel 10.

Tabel 10. Nilai Ukuran Kualitas Akurasi Sarkasme

\begin{tabular}{clcccc}
\hline Metode & 10 Fold Cross & Nilai & Nilai & Nilai & Nilai \\
& Validation & Akurasi & Presisi & Recall & F1Score \\
\hline SVM OAA & Acak & $60,82 \%$ & $88,84 \%$ & $92 \%$ & $70,91 \%$ \\
& Tidak Acak & $60,93 \%$ & $87,80 \%$ & $92 \%$ & $70,66 \%$ \\
SVM OAO & Acak & $60,82 \%$ & $88,27 \%$ & $91.94 \%$ & $70,83 \%$ \\
& Tidak Acak & $60,93 \%$ & $87,80 \%$ & $92 \%$ & $70,66 \%$ \\
\hline
\end{tabular}

\section{KESIMPULAN}

Berdasarkan hasil penelitian yang telah dilakukan dapat disimpulkan bahwa pendeteksian sarkasme pada proses analisis sentimen dapat dilakukan dengan mengunakan metode multiclass SVM adalah SVM OAO dan SVM OAA dengan hasil nilai akurasi yang memiliki nilai yang sama besarnya baik yang dilakukan secara acak maupun tidak acak dengan nilai sebesar 60,82\% dilakukan secara acak dan 60,93\% secara tidak acak. Kemudian untuk nilai presisi OAA memiliki nilai unggul sebesar $88,84 \%$ yang dilakukan secara acak. Dalam hal nilai recall, OAA masih menjadi metode yang lebih baik dan nilainya dilakukan secara acak sebesar 92\%. Terakhir, untuk skor F1, metode SVM OAA juga memiliki nilai yang lebih tinggi yaitu $70.91 \%$ yang dilakukan secara Acak.

\section{SARAN}

Penelitian berikutnya lebih baik mencoba model aau metode lainnya dari multiclass SVM seperti DGSVM.

\section{UCAPAN TERIMA KASIH}

Tim peneliti mengucapkan terima kasih kepada Kementerian Riset dan Teknologi / Badan Riset dan Inovasi Nasional (KEMENRISTEK / BRIN) yang telah memberikan dukungan dan pendanaan untuk penelitian kami melalui Skema Penelitian Dosen Pemula (PDP) 2020, nomor kontrak 052 / UTI / LPPM / E / 1/3 / VII / 2020. 


\section{DAFTAR PUSTAKA}

[1] D. Darwis, E. S. Pratiwi, and A. F. O. 2020, Pasaribu, Data Twitter Komisi Pemberantasan Korupsi Republik Indonesia, J. Ilm. Edutic, Vol. 7, No. 1, pp. 1-11.

[2] J. Komputasi and A. Rahman, 2020, Pendeteksian Sarkasme pada Proses Analisis Sentimen Menggunakan Random Forest Classifier," Vol. 8, No. 2, pp. 50-58.

[3] D. Alita, S. Priyanta, and N. Rokhman. 2019, Analysis of Emoticon and Sarcasm Effect on Sentiment Analysis of Indonesian Language on Twitter, J. Inf. Syst. Eng. Bus. Intell., Vol. 5, No. 2, p. 100, doi: 10.20473/jisebi.5.2.100-109.

[4] Y. Yunitasari, A. Musdholifah, and A. K. Sari. 2019, Sarcasm Detection for Sentiment Analysis in Indonesian Tweets, IJCCS (Indonesian J. Comput. Cybern. Syst., Vol. 13, No. 1, p. 53. doi: 10.22146/ijccs.41136.

[5] D. Alita, Y. Fernando, and H. Sulistiani. 2020, Implementasi Algoritma Multiclass SVM pada Opini Publik Berbahasa Indonesia di Twitter, Vol. 14, No. 2, pp. 86-91.

[6] S. Styawati and K. Mustofa. 2019, A Support Vector Machine-Firefly Algorithm for Movie Opinion Data Classification, IJCCS (Indonesian J. Comput. Cybern. Syst., Vol. 13, No. 3, p. 219, doi: 10.22146/ijccs.41302.

[7] D. A. Pramudita and A. Musdholifah. 2020, GSA to Obtain SVM Kernel Parameter for Thyroid Nodule Classification, IJCCS (Indonesian J. Comput. Cybern. Syst., Vol. 14, No. 1, p. 11, doi: 10.22146/ijccs.41215.

[8] A. R. Isnain, A. Sihabuddin, and Y. Suyanto. 2020, Bidirectional Long Short Term Memory Method and Word2vec Extraction Approach for Hate Speech Detection, IJCCS (Indonesian J. Comput. Cybern. Syst., Vol. 14, No. 2, p. 169, doi: 10.22146/ijccs.51743.

[9] M. A. Assuja and S. Saniati. 2016, Analisis Sentimen Tweet Menggunakan Backpropagation Neural Network, J. Teknoinfo, , doi: 10.33365/jti.v10i2.20.

[10] M. Arbib, D. Ballard, J. Bower, and G. Orban. 1994. Neural Networks Algorithms, Applications, Vol. 7, No. 1. 